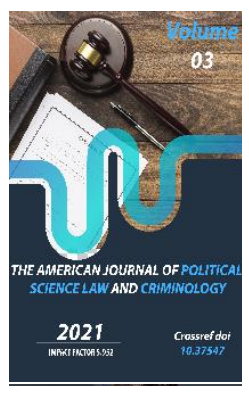

\title{
Formation And Development Of A Legal Mechanism For Combating Corruption: The Experience Of Foreign States
}

\author{
O.A.Yusupdjanov \\ Candidate Of Law, Associate Professor Of UWED, Department Of Theory Of Law And Public \\ Administration, The University Of World Economy And Diplomacy, Uzbekistan
}

Journal Website: http://usajournalshub.c om/index,php/tajpslc

Copyright: Original content from this work may be used under the terms of the creative commons attributes 4.0 licence.

\section{ABSTRACT}

The article analyzes the foreign experience in the fight against corruption. The results of the fight against corruption in those countries where the problems have been solved quite successfully are considered, the role of international cooperation of law enforcement agencies and the efforts of individual international organizations are emphasized.

\section{KEYWORDS}

Corruption; corruption crime; fight against corruption; international legal documents.

\section{INTRODUCTION}

It is important to note that among the most acute social problems facing the modern world, corruption takes a priority place. Corruption is not only closely related to organized and economic crime, as can be seen from analytical documents, forecasts and programs dedicated to the fight against socially dangerous phenomena, but in general 
has a negative impact on the fate of the state, society, and every citizen.

The consequences of corruption harm the state, reduce the level of citizen's trust in the state authorities, and society itself is also negatively affected, which, as a result, contributes to an increase in the processes of destabilization.

In recent years, our country has carried out significant institutional and legal reforms in the field of combating corruption. Systemic measures have been taken to improve the legal awareness and legal culture of the population, and to form an intolerant attitude towards corruption in society.

As part of the implementation of the reforms, the mechanisms for ensuring the protection of the rights and interests of citizens, the openness of the activities of state power and administration, public and parliamentary control have been improved, as well as the legal framework for the activities of law enforcement and judicial bodies has been reformed.

Corruption is an extremely dangerous challenge that destroys the state from within and damages our national security, an uncompromising fight against this phenomenon is the duty of each of us [1].

As rightly noted in the Address of the President of the Republic of Uzbekistan to the Oliy Majlis, if we do not eradicate this vicious phenomenon, we will not be able to create a really favorable business and investment climate, not a single sphere of our society will develop.

Until all strata of the population, the best specialists are involved in the fight against corruption, until our entire society is, figuratively speaking, inoculated with the "vaccine of honesty", we will not be able to achieve our goals. We must move from eliminating the consequences of corruption to its early prevention [2].

\section{THE MAIN FINDINGS AND RESULTS}

A historically significant stage in the reform of the judicial and legal system was the adoption of the Action Strategy in five priority areas of development of the Republic of Uzbekistan in 2017-2021[3], which determined the most important directions of state policy in the field of improving criminal legislation, which implies the implementation of a set of measures to modernize public administration, including reforming the judicial and legal systems, ensuring social justice, in particular, improving the organizational and legal mechanisms for combating corruption and increasing the effectiveness of anti-corruption measures.

The basic document that determined a number of necessary measures in the field of combating corruption was the Law of the Republic of Uzbekistan "On combating corruption", the purpose of which is to regulate relations in the field of fighting corruption.

It should be noted that the fight against corruption is constantly in the focus of attention of the leadership of our Republic. The processes of combating corruption have received even greater strengthening lately. Particularly, in order to improve the efficiency of the anti-corruption system, create the most favorable business climate, promote a positive image of the country in the international arena, as well as in accordance with the tasks defined in the Strategy, the Decree of the President of 
the Republic of Uzbekistan dated June 29, 2020

No. PF-6013 was signed "On additional measures to improve the anti-corruption system in the Republic of Uzbekistan". This document provides for the formation of the Anti-Corruption Agency of the Republic of Uzbekistan. At the same time, this Agency is a specially authorized part of the state, which is responsible for the formation and implementation of state policy in the field of preventing and combating corruption in the republic.

As we know, corruption is a serious obstacle to the implementation of government programs and creates a fertile ground for the growth of crime. Among other things, corruption creates public distrust to the state, it affects, corrodes the judicial system and all legal institutions from within.

This has a negative effect on the development of the country, forms a "double standard" of behavior and morality in society, when the significance of a person and his success depend on his financial situation, which is not always achieved through legal means.

In the political sphere, corruption also plays a negative role, which is expressed in the displacement of the goals of politicians and the destruction of political values. As a result, it leads to the conduct of an unfair political struggle and bribery of officials.

All of the above can ultimately lead not only to negative consequences in all areas, but also cause a response from society.

In Uzbekistan, as in other countries of the world, this problem is extremely urgent and it is obvious that the confident advancement of most modern reforms directly depends on how effectively the fight against corruption will be carried out, therefore, the systematic formation of anti-corruption mechanisms, among which an important place use of legal tools.

The study of the concept of "corruption", as well as the creation, development of methods of combating corruption was paid attention throughout the history of the development of social and humanitarian knowledge.

The concept of "corruption" is found in the writings of Aristotle (in his work "Politics" he singled out corruption as a factor capable of leading the state to degeneration or even to death [4]), N.Machiavelli (who in his work "Sovereign" compared corruption with an illness, which at first difficult to recognize, but easy to treat, and later it is easy to recognize, but almost impossible to treat), T. Hobbes wrote in "Leviathan": "People who pride themselves on their wealth bravely commit crimes in the hope that they will be able to avoid punishment by corrupting the state justice or receive forgiveness for money or other forms of reward" [5].

In the scientific literature, most authors consider corruption not as a legal phenomenon that could be qualified by a specific rule of law (criminal or administrative), but as a criminological, socio-economic phenomenon characterized by a multi-structural and multilevel content [6]. This point of view is shared by S.V.Maksimov, who refers to acts of corruption: bribery; criminal lobbying; patronage based on personal connections; illegal participation in entrepreneurial activity personally or through relatives or proxies; granting exclusive rights to something for personal gain; the acquisition or diversion of public funds and property for their corporate group; direct or indirect contributions during 
election campaigns in favor of certain parties or individuals, as well as for other political purposes; illegal distribution of loans, grants and investments[7].

A slightly different opinion is shared by M.D.Davitadze, who believes that the main crimes with signs of corruption should include: bribery of an official; embezzlement misappropriation or other inappropriate use by an official for the purpose of deriving benefit for himself or another natural or legal person of any state, public, private property that is under the jurisdiction of this official by virtue of his powers; abuse of influence for personal gain; abuse of office; illicit enrichment - a significant increase in the assets of an official in excess of his legal income, which he can reasonably justify; obstruction of justice - the use of physical force, threats, intimidation, promise, offer, provision of an unlawful advantage in order to induce false testimony, interference in the process of testifying or providing evidence; laundering of corruption proceeds [8].

Analyzing these opinions, one can find their similarities and at the same time certain differences. The authors are unanimous in their opinion regarding the subjective side of crimes, where the motive is selfish motives, and the goal is to obtain benefits in an illegal way. The difference of opinion lies in the definition of which crimes should be classified as corruption.

In connection with the above, it seems appropriate to formulate the following definition: Corruption crimes are an illegal act committed by an official due to existing powers, for selfish motives, with the aim of personal enrichment, patronage, granting rights to "illegal carriers" and (or) bribery of other persons. These crimes include the following types of crimes: bribery, abuse of office, obstruction of justice, embezzlement of state property and funds, granting exclusive rights for personal gain and illegal enrichment.

Corruption has an extremely destructive effect on the development of the nation and the state, and also negatively affects economic and socio-political processes. Therefore, each state is focused on combating corruption, through the development and implementation of the legal framework, plans, as well as the creation of preventive mechanisms.

Anti-corruption - the activities of public authority, citizens' self-government bodies, civil society institutions to prevent, identify corruption offenses, and eliminate their consequences.

In this context, the experience of the FRG is useful. In this country, the regulatory framework aimed attacking corruption is very developed. The entire anti-corruption system in Germany is based on the following principles:

- Safeguard the state treasury and competition through a corruption register;

- Create incentives for new business ethics;

- Prohibit officials dismissed from service for providing patronage from being involved in entrepreneurship for 5 years;

- Fill the gaps in laws;

- Maintain authorized control over telephone conversations;

- Regulate the position of the main witness through mitigation of the sentence;

- Improve criminal prosecution by establishing anti-corruption centers;

- Ensure broad publicity of its activities; 
- To strengthen control in order to prevent self-enrichment and abuse of subjective rights [9].

With the increasing sensitivity of the public to the problem of corruption, which is largely facilitated by the media, the number of investigated corruption cases in Germany has increased. In the field of public administration, preventive measures were taken: recommendations were developed to combat corruption in the sphere of legislative and executive power.

The Recommendations were accompanied by a "Guide to Action" intended for managers, since the effectiveness of measures to influence and prevent corruption primarily depends, according to German legislators, on the leaders of the civil service [10].

In accordance with these documents, civil servants do not have the right to engage in entrepreneurial activities personally or through proxies, including to participate in the activities of the board, supervisory board or other body of a company, partnership or enterprise of any other legal form [11].

For any work other than service, an employee must obtain prior authorization from a higher authority. Permission is not required for: accepting guardianship, caring for the sick or infirm, fulfilling testamentary duties, exercising a "free" profession, managing one's own property, teaching and research activities in scientific institutions and establishment [12].

Among the measures aimed at combating corruption, it should be noted the procedure for the employment of persons who have left high government posts. Within a specified period, they must obtain government approval to work in the private sector or to engage in commercial activities, if they were involved. Otherwise, their behavior may be viewed as corrupt [13].

From the experience of fighting corruption in Germany, it can be seen that officials are under almost constant control and there is no period for acquiring connections. In particular, the bodies have authorized officials performing anti-corruption tasks, interdepartmental commissions are being created, a list of positions prone to corruption has been created, the procedure for the employment of persons who have retired, as well as rotation carried out every five years.

Partly for Uzbekistan, this way of fighting corruption is appropriate. Indeed, until now, before the creation of the above-mentioned Agency, there was no organ whose activities were aimed exclusively at combating this phenomenon. It should be noted that until now the implementation of such an anti-corruption factor as the rotation of personnel is not really ensured - there are often cases when a person has been in office for more than 5 years. As for employment, this provision can also be introduced into our legislative system. And this will reduce the level of corruption. Since there are options, when a person who is to resign thinks that it is necessary to establish contacts, create "fertile soil" in that sector, because he has been in it for several years, he knows everyone and everything. And in the aggregate, conditions are created for the development of corruption crimes.

In this regard, the experience of Singapore in overcoming corruption is of interest. At the time of its independence in 1965, Singapore was a country with a very high level of corruption. In a relatively short historical period, this state has gone from a poor country 
to a highly developed one with a high standard of living and post-industrial sectors of the economy. The corruption reduction strategy was complex. A detailed regulation of the activities of officials was carried out, ambiguities in legislative acts were eliminated, which allowed their free interpretation, many permits and licensing were canceled, the principle of the rule of law and equality of all before the law was consistently and rigorously observed, procedures for the activities of authorities were simplified, strict control over compliance with ethical standards was established [14].

Simplifying the procedure for government activities helped Singapore get rid of bureaucracy, thereby reducing the level of corruption.

The Singapore anti-corruption campaign consisted of four elements. The first was the creation of a powerful independent anticorruption service. The second element is the introduction of the presumption of guilt of officials. The third element is a radical increase in the salaries of officials. The fourth element is the formation of independent, objective mass media covering all revealed facts of corruption.

An interesting aspect of "Prevention of Corruption Act" of the Singapore is that the prohibited category of "bribes" includes not only money, gifts, royalties, securities, etc., but also any position, work and contract; any payment, release, repayment of a debt under any loan, obligation and other debts in whole and in part; any other services, preferences, benefits of any kind, including protection from any fine or insolvency, as well as exemption from actions or disciplinary actions; indulgence in the performance of any duty or right in the framework of professional activity. Moreover, this list also includes any offer, attempt or promise of any reward [15].

Exposing and further application of sanctions, demonstration, publication of information about officials who have carried out illegal corrupt acts can serve as a clear example of the consequences of illegal actions by officials. And also demonstrate the effectiveness of the work of judicial and law enforcement agencies.

Likewise, the experience of fighting corruption in Japan is based on the existence of anticorruption norms that are found in many national laws.

A high level of government interference is one of the prerequisites for the persistence of corruption in Japan[16].

On this basis, as one of the methods of fighting corruption, in 2001 "Information Disclosure Law" came into force in Japan. This act guarantees citizens the right to access official information held by government agencies and the ability to appeal to the Disclosure Control Board if the government refuses to release it [17].

In addition, there are the following ways to combat corruption:

$\checkmark \quad$ In Japan, there is control over the spending of officials;

$\checkmark$ Sanctions for corruption affect both parties to a corruption transaction, as well as its intermediaries;

$\checkmark$ There is a prohibition for officials to get a job in private companies after leaving the public service.

It can be noted that the fight against corruption in Japan is being conducted successfully, but there are still ways to circumvent the established prohibitions and 
restrictions. To a large extent, this is facilitated by the mentality of the Japanese, their adherence to centuries-old traditions that establish relations between the population and officials on the principle of family relations, which do not allow "keep it in the family".

Unfortunately, such a negative phenomenon as corruption has not spared our state either. And in our country, such crimes are also often committed by officials, executives who commit one or another illegal act in order to receive gifts, money or services in return.

In order to reduce latent corruption crime, Uzbekistan is carrying out significant work to improve the regulatory framework for state control over the activities of business entities. In particular, the powers of the regulatory bodies and the list of grounds for their interference in the activities of business entities have been limited, the number of inspections has been reduced, duplication of control during their conduct has been eliminated, the forms and methods of their implementation have been improved, clearly substantiated principles for the formation of annual and quarterly plans for inspections of the activities of business entities have been introduced.In the personnel policy, rotation norms are fixed, which, in addition to the tasks of timely and high-quality staffing of state bodies with personnel, operational maneuvering with available human resources, is aimed at preventing corruption, malfeasance and misconduct [18].

Illegal acts on the part of the authorities and administration are punished by the Criminal Code of the Republic of Uzbekistan, which has a list of corpus delicti for which applied punishment by the state. It should be noted that the anti-corruption policy of Uzbekistan is strengthened every year by making changes and additions to regulations, joining the UN Convention against Corruption (in 2008, Uzbekistan joined this international document, which determined a number of necessary measures in the field of combating corruption ), as well as in 2010 - to the Istanbul AntiCorruption Action Plan of the Organization for Economic Cooperation and Development. This was an important stage in the implementation of systemic mechanisms in the field of combating corruption.

As already noted, corruption is one of the factors hindering the development of the state, which affects all spheres of social, political and economic activity. The properties of corruption are its rapid development and rooting.

The fight against corruption remains in the center of attention of our state. Historical experience and modern practice, including in some newly independent states, will allow us to use their experience in improving the anticorruption legislation of the Republic of Uzbekistan.

Therefore, Uzbekistan pays special attention to foreign experience in the field of combating corruption. It is advisable to consider Singapore's experience of "immunity of officials" in a stricter sense, and possibly to make changes to our respective legislation. Since the inviolability enjoyed by officials is currently not functional, i.e. applies not only to the actions performed by them in the performance of their official duties. In this regard, in order to avoid "evasion from responsibility" of such persons, it is necessary, in our opinion, to legislate the extension of immunity only to actions performed by them during the performance of their official duties. 
As mentioned above, corruption has a negative impact on all spheres of society: economy, social sphere, politics. The consequences generated by this phenomenon not only impede the progressive, progressive development of society, but also pose a serious threat to the country's national security interests.

At the same time, for example, in Singapore, the main place in anti-corruption policy is the prevention of corruption through the adoption of measures of state incentives, both in remuneration and in the reporting of public officials on their property, staff rotation, as well as in the severity of punishment for those who commit corruption crimes. In addition, prevention of corruption plays a special role in Singapore.

It is well known that there are no universal ways to combat corruption; each country must choose its own model and system of anticorruption measures based on its internal provisions and national characteristics. The use of foreign experience in combating corruption in our country cannot be carried out by copying anti-corruption measures that were effective in other countries. These measures will always need to be adapted to the national model for application in our country.

However, the successful experience of creating and implementing foreign anticorruption strategies should be carefully studied. In our opinion, taking into account foreign experience will help our country reduce the level of corruption in all sectors of activity.

Based on the foregoing, it is worth considering the following ways of solving this "problem of society":
- Bringing national legislation in accordance with international standards;

- Improvement of the mechanism allowing to ensure information transparency of the decision-making process affecting the interests of the whole society and the state;

- Introduction of a system of civil servants' rotation (based on the experience of Germany and Singapore);

- Strengthening of comprehensive public control over the activities of officials in the civil service.

\section{REFERENCES}

1. President Shavkat Mirziyoyev's Greeting Remark on the Constitution Day. 7.12.2020. available at: https://president.uz/en/lists/view/3990

2. Text of President Shavkat Mirziyoyev's Address to the Oliy Majlis. 24.01.2020 available at: https://president.uz/en/lists/view/3324.

3. Decree of the President of the Republic of Uzbekistan "On the Strategy of Action for the Further Development of the Republic of Uzbekistan" dated February 7, 2017, PF-4947

4. Aristotel. Politika, available at: http://www.gumer.info/bibliotek_Buks /polit/aristot/index.php

5. Gobbs T. (1988), Leviathan, ili Materiya, forma i vlast gosudarstva tserkovnogo i grazhdanskogo / - M.: Mysl, 229p.

6. Artemeva M.V. (2011), Corruption and corruption crimes ["Korruptsiya i korruptsionnye prestupleniya"]. Journal "Yuridicheskaya nauka", №1.

7. Maksimov S.V. (2000), Corruption ["Korruptsiya"]. Zakonnaya 
otvetstvennost: monografiya. M. pp. 43-44

8. DavitadzeM.D. (2000) Corruption: type, causes and consequences ["Korruptsiya: vid, prichiny I posledstviya"] // ["Aktualnye problem borby s korruptsiey I organizovannoy prestupnostyu"]: sb.nauch.st/ pod red. N. G. Kadnikova i M. M. Malykovtseva. M., $56 \mathrm{p}$.

9. Topical Problems of Anti-Corruption Series: Problems of National Security ["Aktualnye problemy protivodeystviya korruptsii"] Seriya: Problemy natsionalnoy bezopasnosti (2008) №6(351), available at: http://www.budgetrf.ru/Publications/ Magazines/VestnikSF/2008/VSF_NEW2 $00807061002 / V S F \_N E W 200807061002$ _P_007.htm

10. MoiseevV.V., ProkuratovV.N. (2012), Anti-corruption in modern Russia ["Protivodeystvie korruptsii v sovremennoy Rossii"] / Monografiya. Orel:APLIT. 335 p.

11. Moiseev V. (2011), European experience in fighting corruption ["Yevropeyskiy opyt borby s korruptsiey"] // Chelovek i trud. № 1011.

12. Moiseev V.V. (2014), Fighting corruption in Russia ["Borba s korruptsiey v Rossii"]// Monografiya. M.: Direkt-Media. $161 \mathrm{p}$.

13. Ibid.

14. Sirotin A. Treating Contagious Greed: Fighting Corruption in Singapore ["Lechenie zaraznoy zhadnosti: Borba s korruptsiey v Singapure"], Anticorruption information base of the website

[Antikorruptsionnaya informatsionnaya baza sayta] «Suda net»:available at: http://center.sudanet.ru/?tag=сингапу $\mathrm{p}$

15. available at: http://www.finexg.ru/osobennostizakonodatelstva-singapura/

16. M. I. Amar (2014), ["Mirovoy opyt borby s korruptsiey: Sbornik materialov nauchnykh seminarov $i$ zasedaniy diskussionnogo kluba"] (2011-2013) - M.,.137 p.

17. This refers to the LawNo. 42 "On access to information held by the administrative authorities" of 1999, See also the text of the Law: SavintsevaM.I. (2006), World experience in fighting corruption: Collection of materials of scientific seminars and sessions of the discussion club ["Pravovye osnovy sovremennoy zhurnalistiki I informatsionnogo obshestva v Yaponii"]; available at: http://www.japaneselaw.ru. - M., 195$217 \mathrm{pp}$.

18. Available at: http://parliament.gov.uz/ru/events/co mmittee/3758 